\title{
Social constructionism and climate science denial
}

\section{Sven Ove Hansson ${ }^{1}$}

Received: 7 November 2019 / Accepted: 17 August 2020 / Published online: 29 August 2020

(C) The Author(s) 2020

\begin{abstract}
It has been much debated whether epistemic relativism in academia, for instance in the form of social constructivism, the strong programme, deconstructionism, and postmodernism, has paved the way for the recent upsurge in science denial, in particular climate science denial. In order to provide an empirical basis for this discussion, an extensive search of the social science literature was performed. It showed that in the 1990s, climate science was a popular target among academic epistemic relativists. In particular, many STS scholars used it as an allegedly clear example of claims by natural scientists that should be treated as mere social constructions, rather than as reports on the actual state of the natural world. A few connections between social constructivists and corporate science denialism were also uncovered, but the extent of such connections could not be determined. With few exceptions, the stream of criticism of climate science from academic relativists has dwindled since the 1990s. One reason for this seems to be that the contrarian position lost its attraction when it became associated with corporate and right-wing propagandists.
\end{abstract}

Keywords Climate science denialism - Epistemic relativism - Social constructivism • Postmodernism $\cdot$ Strong programme $\cdot$ Science and technology studies

\section{Introduction}

In the last few decades, we have seen a remarkable rise of politically influential science denialism, directed in particular at climate and environmental science. ${ }^{1}$ Business interests have had a substantial role in funding these attacks on science (Oreskes and

\footnotetext{
${ }^{1}$ On the various claims made by climate science denialists, see McCright and Dunlop (2000), Hansson (2017a) and Cann and Raymond (2018). Unless otherwise stated, in this article "climate science denialism" refers to denial of the overwhelming scientific evidence of a significant ongoing anthropogenic greenhouse effect that will have serious negative effects on the future climate.
}

Sven Ove Hansson

soh@kth.se

1 Division of Philosophy, Royal Institute of Technology (KTH), Teknikringen 76, 100

44 Stockholm, Sweden 
Conway 2010). Many commentators have also claimed that academics promoting various forms of epistemic relativism paved the way for science denialism. The criticism has targeted traditions such as social constructivism, the strong programme, deconstructionism, postmodernism, and major parts of Science and Technology Studies (STS). ${ }^{2}$ All of these traditions harbour sceptical views on the knowledge claims of natural science, and they have all been accused of providing the (anti)intellectual tools used by science denialists to vilify climate and environmental science.

Already in 2004, Bruno Latour, a leading STS scholar, deplored that argument patterns of the type he is known for were used to support climate science denialism, which he correctly called an "artificially maintained scientific controversy". He asked self-critically whether his own academic activities had contributed to these developments. Perhaps it was now time to completely change directions, from combatting "an excessive confidence in ideological arguments posturing as matters of fact" to acting against "an excessive distrust of good matters of fact disguised as bad ideological biases". He was worried that "our weapons" had been "smuggled through a fuzzy border to the wrong party" (Latour 2004, pp. 226, 227 and 230). Since then, he has developed into a staunch defender of climate science (Kofman 2018).

In a 2017 paper, three STS scholars maintained that STS scholarship had "exactly the scepticism about experts and other elites that now dominates political debate in the US and elsewhere". They proposed that science studies should move in a new direction, and "find a way to justify expertise in general and scientific expertise in particular" (Collins et al. 2017, pp. 580 and 584). In a newspaper article, criminologist Peter McKnight claimed that postmodernism, "a left-wing theory, a theory meant to liberate oppressed communities from the dominance of the ruling classes", had been taken over by right-wing science deniers, whose "wholesale adoption of postmodernist thinking affirms that two can play that game" (McKnight 2017). In much the same vein, Casey Williams, a PhD student in literature, argued that the steady stream of shameless lies from the White House should be no surprise to students of critical theory or philosophy. For decades, scholars in these disciplines have "deconstructed facts, insisted that knowledge is situated and denied the existence of objectivity".

Call it what you want: relativism, constructivism, deconstruction, postmodernism, critique. The idea is the same: Truth is not found, but made, and making truth means exercising power.

The reductive version is simpler and easier to abuse: Fact is fiction, and anything goes. It's this version of critical social theory that the populist right has seized on... (Williams 2017)

Similar criticism has been voiced by Shawn Otto (2016, pp. 171-204), Daniel Dennett (Cadwalladr 2017), Michiko Kakutani (2018), Lee McIntyre (2018), and many others. But others have defended the accused academic traditions, maintaining that there is no connection between academic epistemic relativism and the forms of science denialism that currently contribute to inaction in climate and environmental policies. For instance, Sergio Sismondo, the editor of Social Studies in Science, wrote in an editorial that the "[v]iews and debates within STS about the nature of expertise" are "oddly irrelevant" in

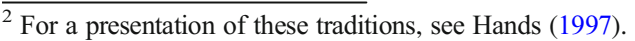


the context of politicized "post-truth" and rejection of scientific expertise (Sismondo 2017 a, p. 4). Further explaining this position, he noted that the bizarre "pizzagate" conspiracy theory was "so far from the kinds of narratives normally seen in STS" that it would be difficult to see any connections (Sismondo 2017b, p. 589). Aaron Hanlon argued for a similar standpoint, and tried to specify what his opponents would have to do in order to prove their case:

If you're going to claim that Trumpism and alt-right relativism are consequences of the academic left's supposition about what was happening, you must demonstrate a causal link. But commentators looking to trace these roots play so fast and loose with causality that they could easily be called postmodernist themselves (Hanlon 2018).

Whether or not epistemic relativism in academia has contributed to the recent upsurge in science denialism is an empirical issue, which should be discussed on the basis of thorough scrutiny of the available documentation. Unfortunately, this is - as Hanlon rightly points out - not how the discussion has usually been conducted.

It is the purpose of the present contribution to investigate whether the available documentation supports the contention that epistemic relativists in academia have contributed to climate science denialism. My study method has been a wide-reaching literature search, using a multitude of bibliographical sources. The search has covered both academic writings and other publications based on or referring to academic work, which can throw light on how researchers in the social sciences and humanities have treated the knowledge claims of climate science. I have also taken notice of their treatment of environmental and health-related science in general. The search has been limited to literature in English, German, French, Spanish and the Scandinavian languages.

In the passage quoted above, Hanlon wrote that in order to show a connection of influence, "you must demonstrate a causal link". This is a rather demanding criterion. Influence is notoriously difficult to demonstrate in full detail (Tosh 2003; Senn 2008; Browning 2010). In the history of ideas, claims on the influence of ideas are commonly made without demonstrations of causal links. To mention just one example, the fact that twentieth century racists who were acquainted with Arthur de Gobineau's (1816-1882) racist writings expressed ideas similar to his is usually taken as evidence enough that his writings influenced them and thereby contributed to twentieth century racism (Biddiss 1966; Nale 2014). More generally, both in scholarly and more colloquial contexts, we usually assume that someone who publicly argues for a standpoint or opinion contributes to its dissemination and adoption. For instance, it is not easy to identify causal links showing that the activities of denialist thinktanks causally contribute to denialist standpoints in politics and media (Lewandowsky et al. 2019, p. 125). In practice, however, their influence on politicians and media outlets seems to be taken for granted both by their funders and their opponents.

In this study I will consider three types of evidence for a connection between on the one hand the traditions of epistemic relativism referred to above and on the other hand climate science denialism: 
Evidence of type 1: Argument patterns: Evidence that academic epistemic relativists have provided argument patterns and ways of reasoning that can be used in support of climate science denialism. ${ }^{3}$

Evidence of type 2: Actual support: Evidence that academic epistemic relativists have themselves expressed opinions supporting climate science denialism.

Evidence of type 3: Acknowledged influence: Evidence that climate science denialists have used or been inspired by the work of academic epistemic relativists, or sought their help or cooperation.

Evidence of types 2 and 3 obviously provide a stronger indication of a connection than evidence of type 1. I have therefore chosen to treat the first type of evidence rather briefly and go more into detail concerning the other two. Evidence of the three types will be presented, in turn, in Sects. 2-4. The findings are further discussed in Sect. 5, and the conclusions are summarized in Sect. 6.

\section{Argument patterns usable for climate science denial}

The first (and weakest) type of evidence is superabundant in the social science literature from the 1970s onwards. The writings of epistemic relativists are full with statements implying for instance that the natural world is a social construction that does not exist independently of human thinking, and that science has no better claim than any other belief system to objective truth about nature. I will mention just a few examples.

In his 1974 book Knowledge and Sociological Theory, Barry Barnes described his own standpoint as "relativistic because it suggests that belief systems cannot be objectively ranked in terms of their proximity to reality or their rationality" (Barnes 1974, p. 154). Two years later David Bloor, the other originator of the Strong Programme, wrote that it "rests on a form of relativism", according to which "all knowledge is relative to the local situation of the thinkers who produce it". In his view, "[t]here need be no such thing as truth, other than conjectural, relative truth, any more than there need be absolute moral standards rather than locally accepted ones. If we can live with moral relativism we can live with cognitive relativism" (Bloor 1976, pp. 142143). In 1987, Elizabeth Ann R. Bird deplored that "[ $\mathrm{t}]$ he conduct of the natural sciences has proceeded under the assumption that scientific knowledge is a representation of something that exists outside it" (Bird 1987, p. 255). She recognized that the rejection of this assumption could undermine environmental protection, and noted the need to "inquire further about the contradiction that scientific knowledge, while socially constructed, is still supposed to be about nature" (ibid, p. 256). In a 1992 essay on risk regulation, Brian Wynne deplored "the obsession with physical risks, and hence with scientific discourses". The problem with this obsession, he said, was that it "deletes deeper questions about institutional behaviour and social relations" (Wynne 1992, p. 755).

\footnotetext{
${ }^{3}$ The term "academic epistemic relativists" covers the rather diverse group of scholars referred to above. As the reader will notice, there is a strong representation of STS scholars in what follows. They seem to be the group of academic epistemic relativists who have most often devoted their studies to issues in the natural sciences.
} 
It should be fairly obvious that standpoints and thought patterns like these can be used to support climate science denialism and other forms of science denialism. This has been pointed out again and again by numerous authors. A statement by Hans Radder from 1992 puts emphasis on the consequences for our thinking and acting in environmental issues:

Consider an environmental issue such as 'the hole in the ozone layer', and suppose that the claimed existence of this hole is, for some reason or other, seen as a problem. According to the ontological relativist point of view, this hole is identical to the discourse about it, and it cannot possibly have any independent reality. Consequently the hole would simply disappear at the very moment we stopped discoursing about it, even if - and this is the crucial point from a normative perspective - we continued employing present technologies, such as aerosols, in an unaltered way! (Radder 1992, p.156)

What Radder said about the ozone hole also applies to climate change. If anthropogenic climate change is a social construction, and other social constructions in which it does not exist are equally valid, then it is difficult to see why we should do anything about it. As absurd as this conclusion is, it seems to be an unavoidable consequence of the strong statements of social constructivism and epistemic relativism that abound in several branches of social science literature from the last half-century.

However, defenders of epistemic relativism have maintained that critics are attacking a strawman. The real social constructivism is said to be much more limited, and there is "little basis for the realists' criticism that social constructivists deny the reality of environmental problems" (Burningham and Cooper 1999, p. 306. See also: Proctor 1998, p. 353; Lockie 2015, p. 139; Sismondo 2017a, b). This is clearly an argument that weakens the critics' case - but only if it is true that academic epistemic relativists have seldom if ever drawn conclusions that deny or belittle climate change and other environmental problems. Whether or not that is true is an empirical issue, to which we will now turn.

\section{Actual support of climate science denialism}

The second and much stronger type of evidence is documentation showing that academic epistemic relativists have themselves expressed opinions supporting climate science denialism. The great surprise of this investigation was the finding that in the early 1990s, climate change was a common target in the writings of epistemic relativists, especially in the STS genre. They treated climate science as a clear and therefore useful example of claims by natural scientists that should be seen as mere social constructions, rather than as reports reflecting the actual state of the natural world.

\subsection{Frederick Buttel and co-workers}

The American sociologist Frederick H. Buttel (1948-2005) was an influential environmental sociologist who served as chair of important sociological organizations and as editor and editorial board member of several scholarly journals (McMichael 2005). In 
the early 1990s, Buttel and his co-workers Peter J. Taylor, Ann P. Hawkins, and Alison G. Power wrote three academic papers in which they applied social constructivism to climate science (Buttel et al. 1990; Buttel and Taylor 1992; Taylor and Buttel 1992). They criticized other social scientists who "assumed that the content of knowledge production in science will mirror the biophysical parameters of the natural world that scientists must inevitably uncover" (Buttel and Taylor 1992, pp. 216-217). This had led to "a premature stress on global-change problem amelioration" in social research (ibid, p. 218). Instead, they applied research strategies such as "[ $\mathrm{t}]$ he strong program (relativism, social constructionism, interpretive) and not-so-strong versions of relativism". These strategies should be used for "demystifying science", in order to treat it as "one of many social modalities by which interests are expressed or served" (ibid, p. 219). Scientific knowledge claims about global climate change should thus be seen "as ordinary social constructions or as derived from interests, political-economic relations, class structure, socially defined constraints on discourse, styles of persuasion, and so on" (ibid p. 220).

In their articles on climate change, Buttel and his co-workers put much reliance on writings by science denialists, whom they described as having a "cautionary position" (Buttel et al. 1990, p. 58) and performing a "[d]econstruction of the science and the action program of global climate change" (Taylor and Buttel 1992, p. 413). They based their conclusions on the 1989 report on climate change from the Marshall Institute, a right-wing think-tank (Buttel et al. 1990, p. 58), and on individual contrarians such as William E. Reifsnyder (Buttel and Taylor 1992, p. 218) and Reid Allen Bryson (Buttel and Taylor 1992, pp. 218 and 223; Buttel 1993a, p. 181). They praised Bryson, who essentially rejected all the evidence of global warming (Bryson 1990) for having "purely scientific grounds" for his standpoint (Buttel and Taylor 1992, p. 223). In contrast, they described writers defending climate science as giving "the appearance of practitioners wanting to cover their tracks, in anticipation of allegations that the atmospheric and ecological sciences may have been guilty of sensationalism and extra-scientific grandstanding" (Buttel et al. 1990, p. 65).

Buttel and his co-workers were well aware that their standpoint was contradicted by an already well-established scientific consensus on the reality of anthropogenic climate change. However, they dismissed that consensus, claiming that there had been a "premature closure on stylized facts of global change", which had led to "a premature stress on global-change problem amelioration" (Buttel and Taylor 1992, p. 218). The increasing focus on climate change and other global environmental issues was "as much or more a matter of the social construction and politics of knowledge production as it is a straightforward reflection of biophysical reality" (Buttel and Taylor 1992, p. 214). But according to Buttel, there were "growing signs of hesitation within the scientific community about the empirical basis of many of global warming's received claims" (Buttel 1993a, p. 181). With a remarkable extension of their own (perceived) field of competence as social scientists, they declared:

We take the position that the current consensus on the greenhouse effect has raced ahead of the quality and quantity of scientific data on the issue, and that scientists and officials of environmental groups have played a major role in this achievement. (Buttel et al. 1990, p. 58) 
They did not present any scientific argumentation for this rejection of what they acknowledged to be "the current consensus". Instead, they chastised the popular press and various politicians, including Margaret Thatcher, for having "accepted that global climate is changing" (Buttel et al. 1990, p. 60). They also criticized other sociologists, who had taken global warming "more or less at face value as established scientific fact" (Buttel and Taylor 1992, p. 218).

In their perspective, it was surprising that global climate change had "gained extraordinary respectability" (Buttel et al. 1990, p. 60). They asked: "Why has it become so widely perceived as scientific fact when its basis in data is hardly airtight?" (Buttel et al. 1990, p. 60) More precisely, they saw a need to "explain why particular kinds of environmental knowledge claims, in particular those positing a global-level dynamic and constructed at a global level of analysis, tend to be privileged over others" (Buttel and Taylor 1992, p. 221). In trying to answer that question, they came up with a couple of tentative explanations. One of these was a well-known sociological allpurpose explanation, namely the "decline of the traditional working class". This had given rise to a "political-ideological vacuum" which was now "filled by what are often referred to as 'new social movements'. The greenhouse-buttressed Green trend is one component of these new forms of political mobilization" (Buttel et al. 1990, p. 63). Another explanation was the business interests of energy companies whose products would become marketable if coal-generated electricity was "taxed or regulated out of existence" (Buttel et al. 1990, p. 63).

Yet another explanation was that global warming "provided a persuasive rhetorical framework" (Buttel et al. 1990, p. 63) for the organizational interests of the environmental movement. The notion of global climate change was "particularly appropriate for aggregating the bulk of the traditional environmental agenda (e.g., industrial pollution control, energy conservation, preservation of tropical ecosystems, population control) under a single umbrella rationale" (Buttel and Taylor 1992, p. 222). In addition, it justified a message of "worldwide alarm or dread", which was particularly useful for the environmental movement (Buttel and Taylor 1992, p. 222). This argument was most clearly expressed by Buttel in an article that was primarily devoted to agricultural sustainability. In that article, he also referred to the 1988 drought in the USA as an important factor. It triggered environmental groups, which "had been aware for several years about the growing speculation within some quarters of the atmospheric science community that the world was in the early stage of a global warming trend" (Buttel 1993a, p. 179). As he saw it, the rhetorical advantages for the movement were substantial:

Global warming and associated themes, such as reducing global environmental change, stemming the depletion of stratospheric ozone, and promoting biodiversity conservation, could serve as a comprehensive, overarching justification for a lengthy agenda of environmental goals. The need to reduce industrial pollution, achieve greater energy conservation, conserve tropical rainforests, and so on could all be justified through one overarching imperative - to stem global warming - rather than each goal having to be justified on its own particular merits. This 'global packaging' was attractive, since it obviated the need for environmentalists to achieve multiple goals in many places simultaneously. (Buttel 1993a, p. 179) 
One obvious explanation why the existence of anthropogenic global warming was so widely accepted is conspicuously absent from their discussion, namely the strength and convincingness of the scientific evidence. One reason for this omission could be that they had adopted methodological neutrality between different knowledge claims, a stance that tends to block explanations that refer to scientific convincingness (Hansson 2007). Alternatively, the reason for this omission could be allegiance to a contrarian standpoint. They called the environmental movement's affirmation of global warming a "noble lie" (Buttel et al. 1990, p. 65), a designation that implies rejection rather than neutrality with respect to the existence of anthropogenic climate change.

Much in line with this, Buttel and his co-authors offered a political argument against the consensus view in climate science. They saw that view as part of a trend towards "globalization of environmental discourse", which was dangerous since it "steers attention away from the differentiated politics and economics of socio-environmental change" (Taylor and Buttel 1992, p. 413). There had been too much attention to "common human interests in environmental conservation", and too little to the often conflicting interests of "different social groups and nations" (Buttel and Taylor 1992, p. 212). In particular, they saw climate mitigation policies as inimical to development in the Global South. Previously, development policies had been opposed "on the grounds that they had unequal socioeconomic effects", but this line of criticism had lost its force. Instead, "environmental symbols" had become the "predominant vocabulary" of discontent with development practices (Buttel et al. 1990, p. 63). In particular, they saw rainforest preservation as an overemphasized "glamour topic" (Taylor and Buttel 1992, p. 411. Cf. Buttel et al. 1990, p. 64).

This new style of development opposition - sometimes called the 'sustainable development' movement - is now particularly focused on tropical rain forests. Over the past few years there has been an increasingly strong tendency for development opponents, in the Third World and elsewhere, to draw on concepts such as global change, global warming, and the greenhouse effect in order to strengthen their legitimacy. (Buttel et al. 1990, p. 63)

In 1993, Frederick Buttel received the yearly Distinguished Award of the Section on Environment and Technology of the American Sociological Association. In connection with the award he was invited to publish a short essay in the society's newsletter. The essay was a de facto retraction of his previous standpoints. He said:

Neither a 'strong programme' dissection of environmental knowledge nor a gratuitous postmodern cultural sociology of environmental beliefs will or should change the reality of global environmental problems. (Buttel 1993b, p. 10)

Furthermore, he now said that global environmental change "in the main is a biophysical reality" (Buttel 1993b, p. 10). This was in sharp contrast to a joint article by him and Peter Taylor from the year before, in which they claimed that global environmental change was "as much or more a matter of the social construction and politics of knowledge production" as of "biophysical reality" (Buttel and Taylor 1992, p. 214). However, that statement was left unchanged when a revised version of the article was published in a book in 1994 (Buttel and Taylor 1994, p. 232). It should also be noted that as late as in 1997, Peter 
Taylor published a book chapter in which he boldly declared: "I oppose global environmentalism". That was because he considered the science on which it was based to "provide inadequate explanations". In his view, "policies based on such science" are "not only unlikely to achieve their intended effects, but also likely to produce undesired ones" (Taylor 1997, p. 162). He also claimed in this chapter that environmental scientists "know there are global environmental problems because they do not know most people do not have problems of a global nature" (Taylor 1997, p. 151).

\subsection{Nicholas Fox}

In response to a call by the chairman of the British Economic and Social Research Council for more sociological research on the environment and climate change, sociologist Nick (Nicholas J.) Fox wrote a short article in which he expressed reticence to the proposal:

We must first consider just how close the whole issue of environmental change it is safe for a subject like sociology to get. How do we know that the predictions of environmental catastrophe are as significant as they are claimed to be? The Greenhouse Effect is a catchphrase of the 1990s, but is it a new paranoia to replace the Cold War, a piece of scientific kite-flying or a 'real' threat? Knowing what we do about scientific knowledge, it could be very foolish for sociologists to assume that the natural world 'really' is changing: consider the consequences for an uncritical sociology of embracing 1900s eugenics or 1970s astrology. (Fox 1991, p. 24)

Importantly, his reservations about sociological research on climate change and other environmental issues were based on general doubts towards scientific knowledge. Three years later, two American sociologists, Riley Dunlap and William Catton, referred to his article and observed that "Fox's heavy emphasis on the social construction of the environment is consistent with the views of a majority of the few American environmental sociologists who have thus far published on GEC [global environmental change]" (Dunlap and Catton 1994, p. 19).

\subsection{William Cronon}

In 1994 William Cronon, a respected environmental historian, criticized his colleague David Demeritt for speaking about global warming without hesitation, "despite the vociferous debates within climatology and atmospheric science about whether global warming is actually taking place". Demeritt had written about what Cronon called "the so-called greenhouse effect", and had done this "as if that constructed knowledge had some objectively persuasive authority". Cronon found this standpoint mystifying unless Demeritt was "in fact a closet realist after all” (Cronon 1994, p. 41). ${ }^{4}$ This criticism was based on Cronon's epistemic relativism, expressed as a conviction that "no science will ever escape its ultimately metaphorical relationship with the world it attempts to

\footnotetext{
${ }^{4}$ This referred to a paper in which Demeritt maintained that a sociological perspective on natural science "makes the atmospheric carbon dioxide measurements at Mauna Loa no less important in helping us reevaluate anthropogenic carbon releases" (Demeritt 1994, p. 33). In an article published 7 years later, Demeritt expressed a much more critical view on climate science, depicting it as "framing and, in that sense, constructing for us the problem of global warming" (Demeritt 2001, p. 308).
} 
represent" (ibid, p. 39). In an article written the next year, he seems to have changed his mind and described global warming as "probably real". However, he still rejected the tools used by climate scientists. He used a report by the contrarian Patrick J. Michaels from the right-wing think-tank Cato Institute to substantiate his rejection of climate modelling, claiming that " $[\mathrm{t}]$ he model's ability to predict the future is no more assured than its proven inability to predict the past" (Cronon 1995, p. 47).

\subsection{Mary Douglas and Aaron Wildavsky}

Mary Douglas's (1921-2007) and Aaron Wildavsky's (1930-1993) highly influential cultural theory of risk was instrumental in stimulating social scientists to account for climate change and other environmental issues in terms of cultural constructions of risk and danger, rather than in terms of social responses to real dangers that exist independently of our (individual or cultural) thought constructions (Douglas and Wildavsky 1982; Antonio and Clark 2015, pp. 340-341). In later work, both its authors have defended contrarian positions on climate change.

In 1992, Aaron Wildavsky wrote an introduction to a climate denialist book by Robert C. Balling (Wildavsky 1992). This text is a diatribe against reduction of greenhouse gas emissions. Such measures would lead to a "deindustrialization" of the United States (p. xvi) and cut "our standard of living to abysmal levels" (p. xxi). Quite consistently with the cultural theory of risk, he dismissed global warming as an "environmental scare" (p. xv). Instead, "the greater danger comes from people who would control our behavior in the name of global warming" (p. xx).

In his posthumously published book But is it True?, Wildavsky tried to prove that a long range of environmental problems are much less serious than what has usually been assumed. His argumentation is largely based on claims made by industry-sponsored sources, rather than on peer-reviewed, independent science, and much of it goes against the scientific consensus. The chapter on global warming is an incoherent compilation of various contrarian claims. He denies evidence of global warming, basing his argument on temperature records for the USA, which comprises $1.9 \%$ of the earth's surface area. Furthermore, he maintains that warming might be altered or reversed by "other factors, like oceans and winds and solar flux" (Wildavsky 1995, p. 397), claims that the earth might as well be cooling, speculates that increased $\mathrm{CO}_{2}$ will enhance conditions for life on earth, etc.

In a 2003 paper, Mary Douglas and two co-authors declared themselves neutral between climate science and its opponents, saying that "we do not assume that one group's predictions are inherently more rational or accurate than another's". They even denied that the issue could be resolved "by making a rational choice on strictly scientific grounds", and instead advocated that one should "maintain and nurture a dynamic plurality of contending points of view" (Douglas et al. 2003, p. 107).

In 2006, Douglas repeated this standpoint. She wrote that in the debates on global warming, "each side devotes large funds to research for new facts about the alleged dangers, but no new facts will resolve the issues. The views are irreconcilable because each party is speaking from a different cultural platform." She based this standpoint on cultural theory, which tells us that neither side is "irrational nor immoral", since they only express "their loyalties and moral principles, and their responsibilities to other members of their society" (Douglas 2006, pp. 9-10). The same message was conveyed 
in a book chapter from the same year in which Douglas and her coauthors dismissed the Intergovernmental Panel on Climate Change as "erosive of democracy" and described "the clear separation of facts and values" as a "flawed" policy precept (Verweij et al. 2006a, p. 20. Also in Verweij et al. 2006b, pp. 839-840).

\subsection{Brian Wynne}

Brian Wynne is a leading sociologist of science and the environment. Between 1994 and 1996 he wrote a series of papers on climate change that have much in common with the papers published by Frederick Buttel and his co-workers a few years earlier.

Wynne expressed strong criticism of what he called "the reductionist idiom of the powerful supercomputer models of the IPCC" (Wynne 1994, p. 174). He described them as "the direct descendants of weather forecasting models which extended their scope from a few days to the outer envelope of viable predictive control of the relevant variables, thought to be about twelve days, and are now extended to try to give credible predictions thirty to forty years hence" (Wynne 1994, p. 172). Due to the problematic nature of these models, it was wrong to describe the conclusions from climate modelling as something that had "been discovered, when in effect it may have been preordained by the culture of modelling" (Wynne 1996, p. 370). Although the IPCC communicated what he called "an ostensibly environmentalist message" (Wynne 1996, p. 366), its conclusions "may be considered as a modernist delusion - not so much in terms of its relationship to physical realities, whatever they may be, but in terms of its apparent expectations of cultural authority and global social purchase" (Wynne 1994, p. 188). He described the contrarian organizations of the hydrocarbon industry in more positive terms. "These actors have been probing the soft spots in GCM [general circulation model] science, and funding critical scientific publicity against the IPCC view" (Wynne 1996, pp. 387-388). In his view, policy decisions should not rely on the results of climate modelling, but instead be based on "a more reflexive environmental position that remains consistent with, and indeed requires, a deconstruction of the dominant global warming science" (Wynne 1996, p. 372).

Wynne was well aware that his arguments could be used to undermine not only climate science, but also the policies and policy proposals that were based on it:

All of these sociological observations about the scientific knowledge of global warming could of course contribute to a deconstruction of the intellectual case for the environmental threat, and thus also to a political demolition of the 'environmentalist' case for internationally effective greenhouse gas controls. (Wynne 1996, p. 372. Cf. Wynne 1994, p. 170)

He emphasized that "we should not be afraid to acknowledge that this does entail questioning the scientific knowledge involved" (Wynne 1996, p. 379). In a joint paper, he and Simon Shackley added the reservation "if it exists" when talking about anthropogenic climate change (Shackley and Wynne 1995, p. 222).

However, Wynne was also eager to point out that his criticism did not "amount to a simple falsification of the scientific knowledge which it "deconstructs"' (Wynne 1996, p. 379). His analysis "does not suggest here that, because science has socially constructed global environmental threats, they do not really exist" (Wynne 1996, p. 374). 
He also made it clear that he did not want to align himself with what he called "the international fossil fuels lobbies and their political friends" (Wynne 1994, p. 170). In order to avoid this, without relying on the scientific consensus, he had to find some other justification for the reduction of greenhouse gases:

If, as we argue, science alone is unable to provide a sufficient basis for underpinning political commitment to policy actions, then a public discussion about the many other possible justifications for acting on the issue of climate change is imperative, not least to ensure the political robustness of present and planned policy actions. (Shackley and Wynne 1995, p. 228)

He does not seem to have done much work to develop these "other possible justifications", and he was aware that "[t]his reopening of such a human domain is not without its own risks" (Wynne 1994, p. 188). I have only been able to find two indications in his texts of the direction in which he wanted to go. One of these was that "the policies most likely to help in combating global warming are worth doing anyway, on social, political, moral and even economic grounds, regardless of what they may or may not do to the environment" (Wynne 1994, p. 188). The other was that although "predictability is far less secure and do-able than science acknowledges", greenhouse gas reductions could be justified by a policy that was "much more precautionary in practice" than the present one (Wynne 1996, p. 375). (Notably, neither of these approaches is "without its own risks". If some measure is justified both for the climate and for some other reason, then it will tend lose in urgency if the former justification is dismissed. Furthermore, measures against a possible threat cannot be expected to receive the same priority if the existence of the threat is considered to be uncertain as if it is considered to be certain.)

Wynne expressed sympathy for the argument by Buttel and coworkers that "dominant scientific knowledge, as constructed in the supercomputer climate models used by the IPCC, reflects developed countries' interests in obscuring the social and political inequities which lie at the heart of global environmental degradation", and he agreed with them that sociologists had erred by "uncritically swallowing global environmental science constructs". In order to rectify this, "sociological deconstruction of global environmental science” was necessary (Wynne 1994, p. 185. Cf. Wynne 1996, p. 378.).

In his later writings, notably in an article from 2010, Wynne has adopted a more positive view of climate modelling. He now maintains that the modelling used by the IPCC "is very different from numerical weather forecasting, where it originated technically in the 1970 s" (Wynne 2010, p. 292. Cf. p. 296.). In response to the socalled Climategate he remarked that whatever human failings it revealed, "the forms of validation of IPCC scientific conclusions and judgements are far more substantial, multi-dimensional and robust than can be seriously damaged by one such allegedly illegitimate specific instance" (Wynne 2010, p. 295). He now emphasizes that the IPCC may in fact be "seriously understating the problem" (Wynne 2010, p. 293. Cf. p. 291.). ${ }^{5}$ Referring back to sociological studies of climate science from the 1990s, he claimed that "the constructivist STS approach to climate scientific knowledge (as with other scientific knowledge) was never about straightforward denial of the propositional claims involved. It was about understanding their conditional validity, and the implicit

\footnotetext{
5 This is a possibility that he indicated already in Wynne (1996, p. 368), but then with much less emphasis.
} 
diverse meanings and alternative potential trajectories, including potential epistemic trajectories, deeply embodied in them and their framing" (Wynne 2010, p. 301). This can be compared to his above-quoted statement from 14 years before that "we should not be afraid to acknowledge that this does entail questioning the scientific knowledge involved" (Wynne 1996, p. 379).

\subsection{Steven Yearley}

In the Handbook of Science and Technology Studies (Jasanoff et al. 1995), which was intended to cover the whole field of STS, Steven Yearley contributed a chapter on environmental studies. The chapter did not show any awareness of the important issues for social science that follow from the scientific consensus on anthropogenic climate change. Instead, he used climate science as an example of problems arising when "scientific expertise is increasingly at the forefront of environmental policy formulation and of contests over policies". He cited only one reference on the natural science involved, namely a popularized summary of a 1991 article about correlations between the solar cycle and the climate (Kerr 1991; Friis-Christensen and Lassen 1991). This article was used by contrarians as an argument against the existence of anthropogenic climate change. Yearley said that if accepted, the claims in this article "could provoke a huge reevaluation of views on global warming. Thus something that scientists 'know' with great certainty at one time may come to be denied with equal confidence at a later stage" (Yearley 1995, p. 463). What he did not mention, however, was that already in 1992, new results had been published that quantified the solar effects discussed in the 1991 article, and showed that the contribution of solar variation to climate change was much smaller than that of anthropogenic greenhouse emissions (Lacis and Carlson 1992; Kelly and Wigley 1992, Schlesinger and Ramankutty 1992). Neither did he mention the IPCC's conclusion in its 1992 report that the new information on solar variations gave no reason to change its previous assessment (IPCC 1992, p. 20). This brief and remarkably inaccurate description of the state of knowledge is, as far as I can see, all that this 820-page handbook on science and technology studies had to say on global climate change.

Yearley's text appears - as might be expected of a handbook chapter - to be in keeping with the state of the field at the time when it was written. In an article published in 1994, sociologists Riley Dunlap and William Catton bemoaned that sociological work on global environmental change had "adopted a staunch constructivist orientation". This, they said, was dangerous, "for if global change is seen as primarily a social construction rather than an objective (albeit imperfectly understood) condition, then it poses little threat to the future of our species." In their view, the dominance of this stance amounted to missing "an enormous opportunity for environmental sociology", namely to study "impacts of humans on the environment as well as the effects of ecological constraints on human societies" (Dunlap and Catton 1994, p. 7).

\subsection{Steve Fuller}

Steve Fuller, a highly acclaimed sociologist of science, is one of the few social scientists who have applied epistemic relativism to climate change in recent years. He is particularly critical of global climate models, which he describes as "the most 
notorious contemporary icon" of models that "enable the user to manipulate the initial parameters by introducing new evidence, resulting in different anticipated outcomes that constitute a new actual world" (Fuller 2015a, pp. 278-279). He has repeatedly referred to the so-called Climategate, which in his view reveals "the micro-processes by which a scientific consensus is normally and literally "manufactured", namely that "scientists from across the world effectively conspired to present the data for climate change in ways that obscured interpretive ambiguities, thereby pre-empting possible appropriations by so-called "climate change sceptics"' (Fuller 2018, p. 22. Cf. Fuller 2017b, pp. 49-50). For him, "the entire episode left questions as to whether scientists can be trusted to provide a disinterested interpretation of their own findings" (Fuller 2015 b, p. 54). His argumentation on climate science sometimes reduces to the simple rhetoric that since scientists have been wrong before, they can be so again:

In my lifetime, scientific predictions surrounding global climate change has [sic] veered from a freezing to a warming version of the apocalypse, based on a combination of improved data, models and, not least, a geopolitical paradigm shift that has come to downplay the likelihood of a total nuclear war. Why, then, should I not expect a significant, if not comparable, alteration of collective scientific judgement in the rest of my lifetime? (Fuller 2015b, pp. 58-59)

In contrast, he describes the critics of climate science in positive terms, calling their activities a "sceptical backlash" to models so constructed that "a slight shift in data points entered into a model could justify unprecedented resource reallocations, especially given the frequency with which such data points have shifted in response to new evidence in the past" (Fuller 2010, pp. 117-118). He claims that the contrarians do not dispute the facts and practices of climate science, but only debate how the facts are "synthesized into a larger world-view that purports to provide the best explanation for all fields of knowledge drawn together" (Fuller 2010, pp. 105-106, cf. p. 102). In one of Fuller's texts, the proponents of climate science are compared to "the resolutely pessimistic Thomas Malthus", and the contrarians to "the boundlessly optimistic Marquis de Condorcet", who ultimately won the debate on population growth. The current debate on global warming is described as the "second round" of this debate, and Fuller is "cautiously optimistic" that Condorcet (i.e. the contrarians) will win this second round (Fuller 2009, p. 144).

\subsection{The general picture}

We have seen that a notable number of social scientists in the 1990s, in particular sociologists in the STS tradition, argued against the scientific consensus on climate change. This would have been less remarkable if a large group of their colleagues were active on the other side, performing social research based on the consensus in climate science. That, however, was not the case. To the contrary, climate change and other environmental issues were remarkably seldom referred to in sociological literature at that time. This has been seen as a consequence of a long tradition in sociology to treat nature as a constant background condition. In the 1990s, several sociologists warned that such "[s]ociology as if nature did not matter" paved the way for interpretations of "environmental issues as socially constructed 'social scares"” (Murphy 1995, pp. 693 
and 690), and called for "a reorientation away from our traditional disciplinary assumption that the biophysical environment is irrelevant to modern, industrialized societies" (Dunlap and Catton 1994, p. 15). But mainstream sociologists showed little interest in these issues. For instance, in his book Beyond Left and Right from 1994, Anthony Giddens mentioned them only briefly, saying that "[w]hether or not global warming is occurring is a contentious matter" (Giddens 1994, p. 219, cf. pp. 3-4). Although he wrote at a time when the consensus on climate change was wellestablished, and IPCC reports and other reliable scientific sources were available, his only reference was to a paper by a denialist economist. Giddens uncritically quoted his claim that the future consequences of greenhouse gas emissions were unknown; "we could frizzle or freeze or there may be no change" (Giddens 1994, p. 203; Lol 1996, p. 156).

As we have seen, the stream of criticism against climate science from academic relativists petered out towards the end of the 1990s and afterwards (with Steve Fuller as a rather unique exception). Unfortunately, there is not much documentation explaining why this happened. A couple of the scholars who ceased or mitigated their criticism have afterwards expressed a more positive view of the scientific evidence on global climate change. We saw in Sect. 3.1 that in 1993, Frederick Buttel expressed belief in "the reality of global environmental problems", seemingly in conflict with his previous writings. We also saw in Sect. 3.5 that in 2010, Brian Wynne expressed a much less critical attitude to climate modelling than in the 1990s.

A reasonable hypothesis could be that these changed attitudes were due to a strengthening of the scientific case for global warming. However, the scientific consensus on the reality of anthropogenic climate change was established already in 1988, the year when the IPCC was formed (Oreskes et al. 2008, pp. 115-116 and 134-135. Cf. Shwed and Bearman 2010). ${ }^{6}$ Although the scientific case has been strengthened ever since then, there does not seem to have been any dramatic change in the period when academic relativists distanced themselves from criticism of climate science. Instead, another major change took place in the early 1990s, namely a considerable politicization of the issue. As late as in 1992, Buttel and Taylor saw a need to explain "the lack of intense corporate opposition to, or attempts at corporate veto of, global warming policies". They proposed that this lack of a corporate counter-reaction "can be explained by the business opportunities that currently popular responses to global environmental change will afford" (Buttel and Taylor 1992, p. 224). They could not have written this a few years later; it was in the early 1990s that corporate climate science denialism made its public appearance (Boykoff and Boykoff 2004, pp. 129133). Clearly, the contrarian position became less convenient and therefore also less attractive when it was forcefully promoted by propagandists paid by large companies. In 1996, Bryan Wynne wrote that it had been "recognized for some time that sociological deconstruction of knowledge may find itself in unwelcome company, politically speaking" (Wynne 1996, p. 363). It is a plausible hypothesis that it was the unwanted political company, rather than the weight of the climatological evidence, that stopped the stream of social constructivist studies rejecting mainstream climate science. Interestingly, this explanation is implied by Steve Fuller in an article in which he reproves other STS scholars for not embracing his own critical stance on climate science:

\footnotetext{
${ }^{6}$ On the current status of the consensus on climate change, see Cook et al. (2016).
} 
What is perhaps most puzzling from a strictly epistemological standpoint is that STS recoils from these tropes whenever such politically undesirable elements as climate change deniers or creationists appropriate them effectively for their own purposes. (Fuller 2017a)

In 2008, sociologist Constance Lever-Tracy wrote an article in which she deplored the low participation of sociologists in research on climate change. In her view, it was due in part to "our continuing foundational suspicion of naturalistic explanations for social facts, which has often led us to question or ignore the authority of natural scientists, even in their own field of study" (Lever-Tracy 2008, p. 452). Her own conclusion was clear:

Since we are not ourselves competent to evaluate the debate between climatologists and sceptics, we have no option but to accept the professional authority and integrity of the accredited experts, on questions of natural processes, as a basis for our own analyses of social causes, consequences and choices. The alternative is irrelevance or worse - an effective complicity with the vested interests of fossil fuel corporations. (Lever-Tracy 2008, p. 457)

In a reply to Lever-Tracy, Reiner Grundmann and Nico Stehr defended the social constructivist approach to natural science that she criticized. Scholars should "explain the success or failure of a scientific theory in the same terms. The outcome of all scientific controversies - successful or not - should be explained by social factors". As they saw it, "there has been little engagement with climate change on the part of sociologists (and especially science studies scholars) because they are aware of the political implications and anxious of not wanting to play into the hands of climate change sceptics" (Grundmann and Stehr 2010, p. 905). ${ }^{7}$ Thus, they agreed with LeverTracy on the reason why so few sociologists were active in research on climate change (criticism of the natural science would lead to unwelcome political company), but they did not concur with her solution (accept the natural science). This observation adds to the plausibility of our hypothesis on the influence of political allegiance on the direction of social constructivist research.

Grundmann, Stehr and several other social scientists with a social constructivist bent co-authored a position paper on climate policy, called the "Hartwell paper". The reality of anthropogenic climate change was not denied, but climate modelling was disparaged with the claim that "the many and varied 'projective' scenarios (that is, explorations of plausible futures using computer models conditioned on a large number of assumptions and simplifications) are sufficient to undergird just about any view of the future that one prefers." In terms of policy they proposed that governments should "switch from the preoccupation with emissions targets" and instead focus on "energy innovation" (Prins et al. 2010, pp. 18 and 34). Several of them are also affiliated with the Breakthrough Institute, an American organization that does not deny the existence of climate change, but nevertheless promotes climate policies that starkly contradict the consensus on what

\footnotetext{
${ }^{7}$ In Grundmann et al. (2012) they repeated this argument, but now with an exceptionally toned down description of constructivism, which they equated with studies of social framings of policy-relevant information. With this approach, the "importance, relevance, and reality" of climate change is not blurred (p. 104).
} 
needs to be done in order to limit its future aggravation; for instance they support the American withdrawal from the Paris agreement and promote increased used of natural gas (Nordhaus 2016; Nordhaus et al. 2017).

\section{Acknowledged influence on climate science denialists}

Section 3 provided evidence that several of the epistemic relativists writing on climate science put reliance on claims originating in what are now considered to be the major loci of climate science denialism, namely think-tanks and individual contrarians associated with business interests and right-wing policies. For instance, (dis)information from the Marshall Institute was used by Buttel and Taylor to throw doubt on conventional climate science, Cronon put outputs from the Cato Institute to similar use, Wildavsky made use of a wide range of contrarian sources, and Fuller promulgates a contrarian interpretation of the so-called Climategate incident.

However, for our present purposes, influence in the other direction is more relevant. The third major type of evidence mentioned in Sect. 1 is documentation showing that climate science denialists have used or been inspired by the work of academic epistemic relativists, or sought their help or cooperation. Two of the researchers figuring in Sect. 3 have exhibited close connections with the right-wing "think-tanks sphere", indicating intellectual community and exchange of ideas concerning climate change. The climate denialist book by Robert C. Balling to which Wildavsky wrote an introduction was published by the Pacific Research Institute for Public Policy, a rightwing think-tank. Aaron Wildavsky was a board member of the Science and Environmental Policy Project (SEPP), which was founded by the right-wing contrarian Fred Singer with funding from the Moon Church (Unification Church). It has also received funding from fossil fuel companies (Wildavsky 1995, p. 345; Scheuering 2004, p. 121 and 125; Singer 1990, p. 65n). Wildavsky has also explicitly used the cultural theory from his 1982 book with Mary Douglas in support of his repudiation of climate change and other environmental problems. He claimed that "individuals choose what to fear to support their way of life", and that those choices can explain why some are so worried about environmental degradation: The "lead against technology", as he calls it, is "taken by people of egalitarian beliefs who wish to weaken corporate capitalism as the source of the inequalities they abhor" (Wildavsky 1995, p. 440). The cultural theory has also been employed by other academics as an argument why a compromise should be struck between the consensus view on climate change and the contrarian view, rather than basing policies on the scientific consensus (Jones 2011, p. 724; Howarth and Sharman 2015).

Since 2016, Steve Fuller is Senior Research Fellow of the The Breakthrough Institute that was mentioned in Sect. 3.8 (Fuller 2019). Fuller's standpoints on climate policies are much in line with those of the Breakthrough Institute. "In the case of climate change", he says, "agreement on the facts of global warming and its likely anthropic source still leaves open whether we should try to stop or adapt to it" (Fuller 2013, p. 755, cf. Fuller 2015a, p. 151-152). Such an "adaptive" strategy "places much greater faith in capitalism", and therefore does not involve "substantially cutting carbon emissions" (ibid, p. 759). Whereas many other STS scholars would avoid the company of right-wing activists fighting climate science, Fuller has a positive view of such a 
potential alliance. In his view, "climate change deniers" do useful work since they "demonstrate that one need not be a politically correct STS practitioner to wield the tropes effectively." They "are actually helping STS by showing the robustness of its core insights as people who otherwise overlap little with the normative orientation of most STS practitioners turn them to what they regard as good effect" (Fuller 2017a).

There are also quite a few examples of cooperation and exchange of ideas between academic epistemic relativists and other branches of right-wing science denial. Steve Fuller actively promotes the "intelligent design" variant of creationism (Lambert 2006), and so does the rhetoric professor John Angus Campbell (Ceccarelli 2011). Perhaps more importantly, Philip Johnson, one of the inventors of the Intelligent Design version of creationism, has based much of his argumentation on postmodernist epistemic relativism, and explicitly refers to the strong programme as one of the tools he uses against evolutionary science (Pennock 2010). Along with the tobacco companies, creationists provided much of the propaganda methods that have been used by climate science deniers (Hansson 2017a).

In an interesting 1996 article, Sheila Jasanoff provided evidence that "US corporate interests (the 'winners' in most accounts of science and politics) are quite eager to exploit the insights of SSK [sociology of scientific knowledge] in their efforts to deconstruct the basis for restrictive health and safety regulations". Being a wellknown scholar in the field, she had been "sounded out at various times about my willingness to give expert advice to a corporate defendant in a lawsuit involving the discharge of dioxin; to alcoholic beverage manufacturers seeking relief from federal regulations; and to asbestos manufacturers wishing to avoid financial responsibility for asbestos removal from public buildings". In neither of these cases did those who (in vain) sought her support ask her to support any specific claim, but "rather to resist an adversary's claims to scientific credibility" (Jasanoff 1996, p. 399). She has also been quoted by corporate toxicologists in support of a case against stringent chemicals regulations (a case which she did not support). Documentation of such attempts from corporate interests to recruit support from academic epistemic relativists is unusual. ${ }^{8}$ Obviously, such attempts can have taken place without leaving any trace in publicly available documentation.

\section{Discussion}

As we saw in Sect. 1, it has been a contested issue whether academic epistemic relativism can be used as a tool for climate science denial. The evidence in Sect. 3 provides a clear answer to that question: the answer is yes, as demonstrated in the 1990s by the many STS scholars and other academic epistemic relativists who themselves applied social constructivism in this way. These findings give rise to a rather obvious question: Why have so many academic epistemic relativists expressed views that we typically associate with climate science denialists from pro-business and right-wing think-tanks? This will be discussed in Sect. 5.1, followed in Sect. 5.2 by a reflection on what this means for philosophy.

\footnotetext{
${ }^{8}$ The only other case that I have found is Evelleen Richard's report that her writings on alternative medicine led to many offers and requests from alternative medicine organizations. (Richards 1996, p. 343)
} 


\subsection{Why so strong support for climate science denialism?}

The support among epistemic relativists of contrarian views on climate science was not an isolated phenomenon. My search of the literature also made it clear that in the same period, STS scholars have espoused and promoted a whole range of standpoints that contradict the scientific consensus in other areas. Creationism was mentioned in Sect. 4.

Two prominent STS scholars promote thoroughly refuted theories about AIDS. Steve Fuller claims that "the jury is still out" on Peter Duesberg's position on AIDS (according to which HIV does not cause AIDS, and antiretroviral therapy causes instead of suppresses the disease) (Fuller 2013, p. 759. Cf. p 755 and Fuller 2015a, p. 151-152). Needless to say, this theory is contradicted by massive and unequivocal scientific evidence (Cohen 1994; Karetnikov 2015). Its dissemination has led to horrifying human tragedy (Kalichman 2009). Since long, Brian Martin actively supports the claim that AIDS was originally spread through a polio vaccine. He has chosen to "intervene as a partisan", and "helped set the agenda for future promotion of the theory". In doing this he "intended to change the way the polio-vaccine-AIDS theory was dealt with" (Martin 1996, p. 245, 257, and 262-263; Martin 2010). This theory has also been convincingly refuted (Worobey et al. 2004). Martin continues to promote it in articles (Martin 2010) and on a website that was still active in August 2020. The continued dissemination of the unfounded claim that polio vaccine carries HIV reportedly contributed to the obstruction of immunization in Nigeria, which resulted in hundreds of polio cases (Butler 2004; Kaufmann and Feldbaum 2009). Martin has also published a paper defending Andrew Wakefield against the measures taken in consequence of his false claim of a link between MMR vaccine and autism, such as the journal's retraction of his fraudulent article (Martin 2015).

Other cases of academic epistemic relativists supporting (rather than just being neutral about) well-refuted claims include Malcolm Ashmore's support of the discredited so-called N-rays (Ashmore 1993; Kragh 1998; Nye 1980), Evelleen Richards's work on vitamin C, in which she has "personally intervened" in favour of Linus Pauling's scientifically untenable claims of positive health effects of that substance (Richards 1996, p. 343; Jacobs et al. 2015), and several cases of postmodernist philosophers expressing approval of holocaust denial (Lipstadt 1994).

In all these cases, as well as those discussed in detail in Sect. 3, we encounter social scientists who assume that they have the competence to judge the work of natural scientists in various specialized areas of research. For instance, Aaron Wildavsky based his assessments of issues in environmental science on appraisals of the natural science performed by himself and by his own graduate and undergraduate students, "most of whom had no scientific background", and who apparently did this for course credits (Wildavsky 1995, p. 3). Similarly, Brian Martin "used a sociological assessment of the issues to help draw a conclusion about the scientific merits of the theory" that AIDS originated in a polio vaccine (Martin 1996, p. 249). He did not offer any explanation of how sociological assessments could overturn findings and conclusions by professional virologists on viral diseases. Martin has also promoted anti-fluoridationism, using what he called the "tools of relativist analysis" to reach conclusions contradicting the majority opinion among specialists (Scott et al. 1990, p. 482). No explanation of these tools was provided, but he criticized other sociologists, who perform "no examination of the scientific evidence, but rely entirely on the endorsements of dental and medical authorities" (Martin 1988, p. 332. Cf. Scott et al. 1990, p. 480). 
Several STS authors have described such deviations from the scientific consensus as typical of their own discipline. In a much quoted article from 1990, Pam Scott, Evelleen Richards and Brian Martin remarked that the epistemic symmetry which they favoured "is almost always more useful to the side with less scientific credibility or cognitive authority" (Scott et al. 1990, p. 490). In another article, Evelleen Richards declared that "it is quite proper for the analyst who $i s$ critical, to set aside the principle of neutrality and claim justice for underdogs" (Richards 1996, p. 346. Cf. Burningham and Coooper 1999, p. 312). Malcolm Ashmore confirmed that the commitment to support underdogs referred to epistemic underdogs, rather than to those who are underdogs in other respects. ${ }^{9}$ He exemplified this with a conflict between a tobacco company and a dying smoker:

For it is the tobacco companies who have lost the fight over smoking and health. No seller of cigarettes can any longer credibly make claims that smoking is (even) harmless, never mind beneficial. This is why it is the tobacco companies, not the dying smoker, who could make use of our - SSK's - form of analytic understanding. As epistemological losers, it is they who are the underdogs. (Ashmore 1996, pp. 314-315)

What made the dying smoker an overdog in relation to the tobacco company was the support that the smoker's case received from "the authority of cognitive credibility, the power that comes from being right, from being on the side of the winners in technoscientific disputes" (Ashmore 1996, p. 314). This is a remarkable statement, since the precept to side with those whose adversaries have "the power that comes from being right" seems to imply that one should side with those whose standpoint has the shortcoming of being wrong.

In a 1996 article, Brian Wynne took another view, namely that the role of underdog belonged to the party that was at a disadvantage in terms of resources, rather than in terms of epistemic success. He conceded that researchers who relied on the assessments of the IPCC could be said to be "siding with the underdog - in this case, presumably, the IPCC when measured against the global hydrocarbons industries and their political allies" (Wynne 1996, p. 368). But there was more to this:

However it is far from clear who is the underdog here, since the poor of the developing world may not appreciate being coerced into environmental controls to avoid something as abstract and distant as global warming. Thus the environmental NGOs and IPCC of the rich world may be seen as supporting the domination of the poor South by the rich North, while the world oil and coal industries weigh in on the side of the world's poorest. (Wynne 1996, p. 368)

This, in his view, had been "a very sensitive issue for the NGOs especially since the 1992 United Nations 'Earth Summit' in Rio” (Wynne 1996, p. 388).

\footnotetext{
${ }^{9}$ Baker and Oreskes (2017, p. 6) described it as "a sad irony that STS, which often sees itself as championing the subaltern, has now in many cases become the intellectual defender of those who would crush the aspirations of ordinary people."
} 
The "underdog ideology", which seems to have had a strong standing in the sociology of science in the 1990s, may be an important part of the explanation why so many social scientists with a relativist bent turned against climate science in that period. However, this can only be an element of a fuller and more satisfactory account, for which a more comprehensive historical study of this heterogeneous academic movement will be needed.

\subsection{What does this mean for philosophy?}

The documentation presented here, in particular in Sect. 3, provides strong indications that academic epistemic relativists have contributed to climate science denialism. It is reasonable to ask whether other academic disciplines have contributed, perhaps less directly, to science denialism. The role of sociology was mentioned in Sect. 3.8. Anthropology has a long history of both moral and epistemic relativism (AAA 1947, p. 540; Brown 2008). Here I will focus on philosophy, my own discipline.

Few philosophers have contributed directly to climate science denial. ${ }^{10}$ However, philosophy appears to have contributed, more indirectly, in at least three ways to the recent upsurge in climate science denial and related phenomena.

First, there is a long-standing tradition to think of philosophy as the superior judge of other academic disciplines. Symptomatically, the latter have often been called "special sciences", a designation popular not least among logical empiricists (Frank 1947). One example of this superior judge attitude is that most philosophical accounts of the demarcation of science employ criteria that can be used by a philosopher without expert knowledge in the scientific field concerned. ${ }^{11}$ This attitude among philosophers may well have inspired similar attitudes among sociologists of science, as described in Sect. 5.1. The risk that this cavalier attitude to specialized expertise will lead to misjudgements is essentially the same in sociology as in philosophy.

Secondly, philosophers of science have treated scientific knowledge as a unique type of knowledge, incomparable to all other forms of human knowledge. As I have argued elsewhere (Hansson 2018), quite impressive fact-finding practices, devoted to finding and systematizing knowledge in various areas, have been present far back in human history. They can be found in illiterate societies, and quite a few of them operate in present-day modern societies in parallel to academic science (e.g. investigative journalism, criminal investigation, and troubleshooting in various technological systems). Modern science can be much better understood as a collection of unusually resourceful and globalized fact-finding practices than if taken to be an unpeered form of human thinking that arose in Europe half a millennium ago. By neglecting these connections, philosophers of science have arguably contributed to an unwarranted science elitism that opened the field for counter-reactions opposing science due to its connections with power and its epistemic monopoly.

Thirdly, philosophy has sown a dragon-seed by its way of teaching the method of philosophical scepticism, or radical doubt (Hansson 2017b). By doubting what we

\footnotetext{
${ }^{10}$ Jerome Ravetz claimed that "Climategate" showed that the evidence of "carbon-based anthropogenic global warming" was insufficient (Ravetz 2012, pp. 137 and 143-144. Cf. Ravetz 2011.).

${ }^{11}$ Popper's criterion of falsifiability is a clear example of this (Hansson 2006). For a demarcation criterion that requires judgments by experts in the relevant field(s), see Hansson (2013).
} 
usually do not doubt - such as each other's existence - and continuing to raise doubts as long as it is at all logically possible to do so, the philosophical sceptic can distinguish between different forms of knowledge and knowledge claims. Radical doubt is an efficient epistemic tool, useful for probing the strength and the foundations of seemingly immutable claims of knowledge. However, it cannot help us determine what is reasonable to believe. For that we need other, mostly area-specific, tools. But unfortunately, we philosophers have largely failed to explain the limited usefulness of the method. Much too often, it has been used or emulated in inappropriate ways and for purposes for which it is unsuitable. In particular, it has often been applied only to (targeted parts of) science, while leaving non-scientific knowledge claims unchallenged. For instance, corporate anti-environmentalists have repeatedly applied inordinate criticism selectively to the parts of science that they are paid to attack, such as evidence of anthropogenic climate change and of the negative health effects of passive smoking. In this way, a philosophical tool has been converted into a tool of disinformation.

Like all academic disciplines, philosophy should be conducted in accordance with research ethics, which includes attention to possible dangerous uses of the research outputs (Hansson 2015, 2017c). The method of radical doubt may very well be our "virus in the laboratory". Pseudoscientists are eager to pick up ideas from philosophy and use them for their own purposes. This applies not least to ideas from the philosophy of science. For instance, de Melo Martín's and Intemann's (2014) article on scientific dissent, which offers no support of pseudoscience, was quoted by an HIV/AIDS denialist in support of of his position (Rasnick 2015, p. 80). One example of a potentially affected area is the role of (non-epistemic) values in the process of determining what statements should be assented to in science. We know at least since the 1950s that values have such a role in practice, which in some cases appears to be legitimate (Rudner 1953). However, we also know that without a limit to the influence of values in this process, science cannot fulfil its purpose. ${ }^{12}$ Positions in this debate that provide no clear limit for when evidence can be overridden by values (Brown 2013; Brown 2017; Clough 2008) can be useful for the philosophical discussion, and should by no means be excluded. But they are also an example of ideas whose presentation should be informed by careful ethical reflection on the risk of misuse.

\section{Conclusion}

An extensive search of the literature showed that in the 1990s, climate science was a popular target among academic epistemic relativists. They used it as an allegedly clear example of claims by natural scientists that should be seen as mere social constructions, rather than as reports on the actual state of the natural world. A few connections between these epistemic relativists and corporate science denialists were also uncovered, but the documentation is insufficient to determine the extent of these connections. The stream of criticism of climate science from epistemic relativists has petered out since the late 1990s. One reason for this seems to have been that the contrarian position lost its attraction when it became associated with corporate and right-wing propaganda.

$\overline{{ }^{12} \text { For a proposal on how to draw }}$ that limit, see Hansson (2017d). 
In 1996, Sheila Jasanoff wrote that "we may reasonably be asked to cultivate a reflexive self-awareness of the ways in which our scholarly work may play out in the arena of the "real world"' (Jasanoff 1996, p. 409). Today, this advice is equally valid and even more urgent.

Acknowledgments I would like to thank two referees for highly useful comments on an earlier version of this article.

Funding Open access funding provided by Royal Institute of Technology.

Open Access This article is licensed under a Creative Commons Attribution 4.0 International License, which permits use, sharing, adaptation, distribution and reproduction in any medium or format, as long as you give appropriate credit to the original author(s) and the source, provide a link to the Creative Commons licence, and indicate if changes were made. The images or other third party material in this article are included in the article's Creative Commons licence, unless indicated otherwise in a credit line to the material. If material is not included in the article's Creative Commons licence and your intended use is not permitted by statutory regulation or exceeds the permitted use, you will need to obtain permission directly from the copyright holder. To view a copy of this licence, visit http://creativecommons.org/licenses/by/4.0/.

\section{References}

American Anthropological Association, Executive Board. (1947). Statement on human rights. American Anthropologist, 49(4), 539-543.

Antonio, R. J., \& Clark, B. (2015). The climate change divide in social theory. In R. E. Dunlap \& R. J. Brulle (Eds.), Climate change and society (pp. 333-368). Oxford: Oxford University Press.

Ashmore, M. (1993). The theatre of the blind: Starring a promethean prankster, a phoney phenomenon, a prism, a pocket, and a piece of wood. Social Studies of Science, 23(1), 67-106.

Ashmore, M. (1996). Ending up on the wrong side: Must the two forms of radicalism always be at war? Social Studies of Science, 26(2), 305-322.

Baker, E., \& Oreskes, N. (2017). It's no game: Post-truth and the obligations of science studies. Social Epistemology Review and Reply Collective, 6(8), 1-10.

Barnes, B. (1974). Scientific knowledge and sociological theory. London: Routledge.

Biddiss, M. D. (1966). Gobineau and the origins of European racism. Race, 7(3), 255-270.

Bird, E. A. R. (1987). The social construction of nature: Theoretical approaches to the history of environmental problems. Environmental Review, 11, 255-264.

Bloor, D. (1976). Knowledge and social imagery. London: Routledge.

Boykoff, M. T., \& Boykoff, J. M. (2004). Balance as bias: Global warming and the US prestige press. Global Environmental Change, 14(2), 125-136.

Brown, M. J. (2013). Values in science beyond underdetermination and inductive risk. Philosophy of Science, $80(5), 829-839$.

Brown, M. J. (2017). Values in science: Against epistemic priority. In K. C. Elliott \& D. Steel (Eds.), Current controversies in values and science (pp. 64-78). London: Routledge.

Browning, G. (2010). Agency and influence in the history of political thought: The agency of influence and the influence of agency. History of Political Thought, 31(2), 345-366.

Bryson, R. A. (1990). Will there be a global 'greenhouse warming'? Environmental Conservation, 17, 97-99.

Burningham, K., \& Cooper, G. (1999). Being constructive: Social constructionism and the environment. Sociology, 33(2), 297-316.

Butler, D. (2004). Nigerian states disrupt campaign to eradicate polio. Nature, 428, 109.

Buttel, F. H. (1993a). The sociology of agricultural sustainability: Some observations on the future of sustainable agriculture. Agriculture, Ecosystems and Environment, 46, 175-186.

Buttel, F. H. (1993b). Environmental sociology as science and social movement. Environment, Technology, and Society. Newsletter of the Section on Environment and Technology of the American Sociological Association no, 73, 10-11. 
Buttel, F. H., Hawkins, A. P., \& Power, A. G. (1990). From limits to growth to global change: Constraints and contradictions in the evolution of environmental science and ideology. Global Environmental Change, 1(1), 57-66.

Buttel, F. H., \& Taylor, P. J. (1992). Environmental sociology and global environmental change: A critical assessment. Society \& Natural Resources, 5(3), 211-230.

Buttel, F., \& Taylor, P. (1994). Environmental sociology and global environmental change: a critical assessment. In M. Redclift \& T. Benton (Eds.), Social Theory and the Global Environment (pp. 228255). London: Routledge.

Brown, M. F. (2008). Cultural Relativism 2.0. Current Anthropology, 49(3), 363-373 and 379-383.

Cadwalladr, C. (2017). Daniel Dennett: 'I begrudge every hour I have to spend worrying about politics'. The Guardian, February 12.

Cann, H. W., \& Raymond, L. (2018). Does climate denialism still matter? The prevalence of alternative frames in opposition to climate policy. Environmental Politics, 27(3), 433-454.

Ceccarelli, L. (2011). Manufactured scientific controversy: Science, rhetoric, and public debate. Rhetoric \& Public Affairs, 14(2), 195-228.

Clough, S. (2008). Solomon's empirical/non-empirical distinction and the proper place of values in science. Perspectives on Science, 16(3), 265-279.

Cohen, J. (1994). The Duesberg phenomenon. Science, 266(5191), 1642-1644.

Collins, H. M., Evans, R. J., \& Weinel, M. (2017). STS as science or politics? Social Studies of Science, 47(4), $580-586$.

Cook, J., Oreskes, N., Doran, P. T., Anderegg, W. R. L., Verheggen, B., Maibach, E. W., Carlton, J. S., Lewandowsky, S., Skuce, A. G., Green, S. A., Nuccitelli, D., Jacobs, P., Richardson, M., Winkler, B., Painting, R., \& Rice, K. (2016). Consensus on consensus: A synthesis of consensus estimates on humancaused global warming. Environmental Research Letters, 11, 048002.

Cronon, W. (1994). Comment: Cutting loose or running aground. Journal of Historical Geography, 20(1), $38-43$.

Cronon, W. (1995). Introduction: In search of nature. In W. Cronon (Ed.), Uncommon ground. Toward reinventing ature (pp. 23-68). New York: W.W. Norton.

Demeritt, D. (1994). Ecology, objectivity and critique in writings on nature and human societies. Journal of Historical Geography, 20(1), 22-37.

de Melo-Martín, I., \& Intemann, K. (2014). Who's afraid of dissent? Addressing concerns about undermining scientific consensus in public policy developments. Perspectives on Science, 22(4), 593-615.

Demeritt, D. (2001). The construction of global warming and the politics of science. Annals of the Association of American Geographers, 91(2), 307-337.

Douglas, M.. (2006). A history of grid and group cultural theory. Downloaded September 26, 2019, from http://projects.chass.utoronto.ca/semiotics/cyber/douglas1.pdf

Douglas, M., \& Wildavsky, A. (1982). Risk and culture: an essay on the selection of technological and environmental dangers. Berkeley: University of California Press.

Douglas, M., Thompson, M., \& Verweij, M. (2003). Is time running out? The case of global warming. Daedalus, 132(2), 98-107.

Dunlap, R. E., \& Catton, W. R. (1994). Struggling with human exemptionalism: The rise, decline and revitalization of environmental sociology. American Sociologist, 25(1), 5-30.

Fox, N. (1991). Green sociology. Network. Newsletter of the British Sociological Association, no, 50(May), 23-24.

Frank, P. (1947). The institute for the Unity of science. Synthese, 6(3), 160-167.

Friis-Christensen, E., \& Lassen, K. (1991). Length of the solar cycle: An indicator of solar activity closely associated with climate. Science, 254(5032), 698-700.

Fuller, S. (2009). In search of sociological foundations for the project of humanity. History of the Human Sciences, 22(2), 138-145.

Fuller, S. (2010). Postmodernism's epistemological legacies: Objects without purpose, movement without direction and freedom without necessity. Revue Internationale de Philosophie, 251, 101-120.

Fuller, S. (2013). Manufactured scientific consensus: A reply to Ceccarelli. Rhetoric \& Public Affairs, 16(4), $753-760$.

Fuller, S. (2015a). Knowledge: The philosophical quest in history. London: Routledge.

Fuller, S. (2015b). Customised science as a reflection of 'protscience'. Epistemology \& Philosophy of Science, 46(4), 52-69.

Fuller, S. (2017a). Is STS all talk and no walk? EASST Review, 36(1), 21-22.

Fuller, S. (2017b). Veritism as fake philosophy: Reply to Baker and Oreskes. Social Epistemology Review and Reply Collective, 6(10), 47-51. 
Fuller, S. (2018). What can philosophy teach us about the post-truth condition. In M. A. Peters et al. (Eds.), Post-Truth, Fake News (pp. 13-26). Singapore: Springer.

Fuller, S. (2019). Curriculum Vitae, as of March 1, 2019. Downloaded September 30, 2019 from https://warwick.ac.uk/fac/soc/sociology/staff/sfuller/.

Giddens, A. (1994). Beyond left and right: The future of radical politics. Cambridge: Polity Press.

Grundmann, R., Rhomberg, M., \& Stehr, N. (2012). Der Klimawandel und die Rolle der Sozialwissenschaften. In H. Eigner \& M. Schmid (Eds.), Jenseits traditioneller Wissenschaft? Zur Rolle von Wissenschaft in einer vorsorgenden Gesellschaft (pp. 95-110). München: Oekom.

Grundmann, R., \& Stehr, N. (2010). Climate change: What role for sociology? A response to Constance Lever-Tracy. Current Sociology, 58(6), 897-910.

Hands, D. W. (1997). Conjectures and reputations: The sociology of scientific knowledge and the history of economic thought. History of Political Economy, 29(4), 695-739.

Hanlon, A. (2018). "Postmodernism didn't cause Trump. It explains him", Washington Post, August 31.

Hansson, S. O. (2006). Falsificationism falsified. Foundations of Science, 11, 275-286.

Hansson, S. O. (2007). Against programmatic ignorance. Theoria, 73(2), 95-97.

Hansson, S. O. (2013). Defining pseudoscience - and science. In M. Pigliucci \& M. Boudry (Eds.), The philosophy of pseudoscience (pp. 61-77). Chicago: Chicago University Press.

Hansson, S. O. (2015). The ethics of doing philosophy. Theoria, 81(2), 93-96.

Hansson, S. O. (2017a). Science denial as a form of pseudoscience. Studies in History and Philosophy of Science, 63, 39-47.

Hansson, S. O. (2017b). The uses and misuses of philosophical scepticism. Theoria, 83(3), 169-174.

Hansson, S. O. (2017c). The ethics of doing ethics. Science and Engineering Ethics, 23(1), 105-120.

Hansson, S. O. (2017d). How values can influence science without threatening its integrity. In H. Leitgeb, I. Niiniluoto, P. Seppälä, \& E. Sober (Eds.), Logic, methodology and philosophy of science - Proceedings of the 15th International Congress (pp. 207-221). London: College Publications.

Hansson, S. O. (2018). How connected are the major forms of irrationality? An analysis of pseudoscience, science denial, fact resistance and alternative facts. Mètode Science Study Journal, 8, 125-131.

Howarth, C. C., \& Sharman, A. G. (2015). Labeling opinions in the climate debate: A critical review. Wiley Interdisciplinary Reviews: Climate Change, 6(2), 239-254.

IPCC. (1992). Climate Change: The 1990 and 1992 assessments. Intergovernmental panel on climate change. Downloaded September 2019 from https:/www.ipcc.ch/site/assets/uploads/2018/05/ipcc_90_92_ assessments_far_full_report.pdf.

Jacobs, C., Hutton, B., Ng, T., Shorr, R., \& Clemons, M. (2015). Is there a role for oral or intravenous ascorbate (vitamin C) in treating patients with cancer? A systematic review. The Oncologist, 20(2), 210223.

Jasanoff, S. (1996). Beyond epistemology: Relativism and engagement in the politics of science. Social Studies of Science, 26(2), 393-418.

Jasanoff, S., Markle, G. E., Peterson, J. C., \& Pinch, T. (Eds.). (1995). Handbook of science and technology studies. Thousand Oaks: Society for Social Studies of Science and Sage Publications.

Jones, M. D. (2011). Leading the way to compromise? Cultural theory and climate change opinion. PS: Political Science \& Politics, 44(4), 720-725.

Kakutani, M. 2018. The death of truth: How we gave up on facts and ended up with Trump. The Guardian, July 14.

Kalichman, S. (2009). Denying AIDS. Conspiracy theories, pseudoscience, and human tragedy. New York: Springer.

Karetnikov, A. (2015). Commentary: Questioning the HIV-AIDS hypothesis: 30 years of dissent. Frontiers in Public Health, 3, 193.

Kaufmann, J. R., \& Feldbaum, H. (2009). Diplomacy and the polio immunization boycott in northern Nigeria. Health Affairs, 28(4), 1091-1101.

Kelly, P. M., \& Wigley, T. M. L. (1992). Solar cycle length, greenhouse forcing and global climate. Nature, 360(6402), 328-330.

Kerr, R. A. (1991). Could the sun be warming the climate? Science, 254(5032), 652-654.

Kofman, A. (2018). Bruno Latour, the post-truth philosopher, mounts a defense of science. New York Times Magazine, October 25.

Kragh, H. (1998). Social constructivism, the gospel of science, and the teaching of physics. Science \& Education, 7(3), 231-243.

Lacis, A. A., \& Carlson, B. E. (1992). Keeping the sun in proportion. Nature, 360, 297.

Lambert, K. (2006). Fuller's folly, Kuhnian paradigms, and intelligent design. Social Studies of Science, 36(6), $835-842$. 
Latour, B. (2004). Why has critique run out of steam? From matters of fact to matters of concern. Critical Inquiry, 30, 225-248.

Lever-Tracy, C. (2008). Global warming and sociology. Current Sociology, 56(3), 455-466.

Lewandowsky, S., Pilditch, T. D., Madsen, J. K., Oreskes, N., \& Risbey, J. S. (2019). Influence and seepage: An evidence-resistant minority can affect public opinion and scientific belief formation. Cognition, 188, $124-139$.

Lipstadt, D. E. (1994). Denying the holocaust. The growing assault on truth and memory. Plume: New York.

Lockie, S. (2015). What is environmental sociology? Environmental Sociology, 1(3), 139-142.

Lol, D. (1996). The limits of international cooperation. In G. E. Wood (Ed.), Explorations in economic liberalism: the Wincott lectures (pp. 141-171). New York: St. Martin's Press.

McIntyre, L. (2018). Post-truth. Cambridge: MIT.

Martin, B. (1988). Analyzing the fluoridation controversy: Resources and structures. Social Studies of Science, 18(2), 331-363.

Martin, B. (1996). Sticking a needle into science: The case of polio vaccines and the origin of AIDS. Social Studies of Science, 26, 245-276.

Martin, B. (2010). How to attack a scientific theory and get away with it (usually): The attempt to destroy an origin-of-AIDS hypothesis. Science as Culture, 19(2), 215-239.

Martin, B. (2015). On the suppression of vaccination dissent. Science and Engineering Ethics, 21(1), 143157.

McCright, A. M., \& Dunlap, R. E. (2000). Challenging global warming as a social problem: An analysis of the conservative movement's counter-claims. Social Problems, 47(4), 499-522.

McKnight, P. (2017). Trump as postmodernist: Truth no longer bound by facts. The Globe and Mail, 28 January.

McMichael, P. D. (2005). Dedication: To Frederick H. Buttel. In Buttel, F. H. \& McMichael, P. D. New directions in the sociology of global development (pp. xi-xii). Research in Rural Sociology and Development, Volume 11. Elsevier.

Murphy, R. (1995). Sociology as if nature did not matter: An ecological critique. British Journal of Sociology, 46(4), 688-707.

Nale, J. (2014). Arthur de Gobineau on blood and race. Critical Philosophy of Race, 2(1), 106-124.

Nordhaus, T. (2016). Don't let the planet Bern. USA Today, March 10. Downloaded September 29, 2019 from https://eu.usatoday.com/story/opinion/2016/03/10/bernie-sanders-energy-plan-anti-emissionsreduction-nuclear-natural-gas-column/81500436/.

Nordhaus, T., Trembath, A, \& Lovering, J. (2017). Climate policy in the age of Trump. A plausible path forward. Foreign Affairs, January 24. Downloaded September 29, 2019 from https:/www.foreignaffairs. com/articles/north-america/2017-01-24/climate-policy-age-trump.

Nye, M. J. (1980). N-rays: An episode in the history and psychology of science. Historical Studies in the Physical Sciences, 11(1), 125-156.

Oreskes, N., \& Conway, E. M. (2010). Merchants of doubt: How a handful of scientists obscured the truth on issues from tobacco smoke to global warming. New York: Bloomsbury Press.

Oreskes, N., Conway, E. M., \& Shindell, M. (2008). From chicken little to Dr. Pangloss: William Nierenberg, global warming, and the social deconstruction of scientific knowledge. Historical Studies in the Natural Sciences, 38(1), 109-152.

Otto, S. (2016). The war on science: Who's waging it, why it matters, what we can do about it. Minneapolis: Milkweed Editions.

Pennock, R. T. (2010). The postmodern sin of intelligent design creationism. Science \& Education, 19(6-8), 757-778.

Prins, Gwyn et al. (2010). The Hartwell paper. A new direction for climate policy after the crash of 2009. Downloaded May 24, 2020 from http://eprints.lse.ac.uk/27939/1/HartwellPaper_English_version.pdf.

Proctor, J. D. (1998). The social construction of nature: Relativist accusations, pragmatist and critical realist responses. Annals of the Association of American Geographers, 88(3), 352-376.

Radder, H. (1992). Normative reflexions on constructivist approaches to science and technology. Social Studies of Science, 22, 141-173.

Rasnick, D. (2015). The tyranny of dogma. Journal of Information Ethics, 24(2), 76-95.

Ravetz, J. (2011). 'Climategate'and the maturing of post-normal science. Futures, 43(2), 149-157.

Ravetz, J. (2012). The significance of the Hamburg workshop: Post-normal science and the maturing of science. Nature and Culture, 7(2), 133-150.

Richards, E. (1996). (un) boxing the monster. Social Studies of Science, 26(2), 323-356.

Rudner, R. (1953). The scientist qua scientist makes value judgments. Philosophy of Science, 20, 1-6. 
Scheuering, R. W. (2004). Shapers of the great debate on conservation. A biographical dictionary. Westport: Greenwood Press.

Schlesinger, M. E., \& Ramankutty, N. (1992). Implications for global warming of intercycle solar irradiance variations. Nature, 360(6402), 330-333.

Scott, P., Richards, E., \& Martin, B. (1990). Captives of controversy. The Myth of the Neutral Social Researcher in Contemporary Scientific Controversies. Science, Technology, \& Human Values, 15(4), $474-494$.

Senn, P. R. (2008). The theory and measurement of influence in the history of economic thought. In J. G. Backhaus (Ed.), Political economy, linguistics and culture. Crossing bridges (pp. 15-43). New York: Springer.

Shackley, S., \& Wynne, B. (1995). Global climate change: The mutual construction of an emergent sciencepolicy domain. Science and Public Policy, 22(4), 218-230.

Shwed, U., \& Bearman, P. S. (2010). The temporal structure of scientific consensus formation. American Sociological Review, 75(6), 817-840.

Singer, F. S. (1990). Environmental strategies with uncertain science. Regulation, 13, 65-70.

Sismondo, S. (2017a). Post-truth? Social Studies of Science, 47(1), 3-6.

Sismondo, S. (2017b). Casting a wider net: A reply to Collins, Evans and Weinel. Social Studies of Science, 47(4), 587-592.

Taylor, P. J. (1997). How do we know we have global environmental problems? Undifferentiated sciencepolitics and its potential reconstruction. In P. Taylor, S. E. Halfon, \& P. N. Edwards (Eds.), Changing life: Genomes, ecologies, bodies, commodities (pp. 149-174). Minneapolis: University of Minnesota Press.

Taylor, P. J., \& Buttel, F. H. (1992). How do we know we have global environmental problems? Science and the globalization of environmental discourse. Geoforum, 23(3), 405-416.

Tosh, N. (2003). Anachronism and retrospective explanation: In defence of a present-centred history of science. Studies in History and Philosophy of Science, 34(3), 647-659.

Verweij, M., Douglas, M., Ellis, R., Engel, C., Hendriks, F., Lohmann, S., Ney, S., Rayner, S., \& Thompson, M. (2006a). The case for clumsiness. In M. Verweij \& M. Thompson (Eds.), Clumsy solutions for a complex world. Governance, politics, and plural perceptions (pp. 1-27). Palgrave Macmillan: London.

Verweij, M., Douglas, M., Ellis, R., Engel, C., Hendriks, F., Lohmann, S., Ney, S., Rayner, S., \& Thompson, M. (2006b). Clumsy solutions for a complex world: The case of climate change. Public Administration, 84(4), 817-843.

Wildavsky, A. (1992). Global warming as a means of achieving an egalitarian society: An introduction. In R. C. Balling Jr. (Ed.), The heated debate. Greenhouse predictions versus climate reality ( $\mathrm{pp} . \mathrm{xv}-\mathrm{xxxvi}$ ). San Francisco: Pacific Research Institute for Public Policy.

Wildavsky, A. (1995). But is it true? A citizen's guide to environmental health and safety issues. Cambridge: Harvard University Press.

Williams, C. (2017). Has Trump stolen philosophy's critical tools?. New York Times, April 17.

Worobey, M., Santiago, M. L., Keele, B. F., Ndjango, J.-B. N., Joy, J. B., Labama, B. L., Dhed'a, B. D., et al. (2004). Origin of AIDS: Contaminated polio vaccine theory refuted. Nature, 428(6985), 820.

Wynne, B. (1992). Carving out science (and politics) in the regulatory jungle. Social Studies of Science, 22, $745-758$.

Wynne, B. (1994). Scientific knowledge and the global environment. In M. Redclift \& T. Benton (Eds.), Social theory and the global environment (pp. 169-189). London: Routledge.

Wynne, B. (1996). SSK's identity parade: Signing-up, off-and-on. Social Studies of Science, 26(2), 357-391.

Wynne, B. (2010). Strange weather, again. Theory, Culture and Society, 27(2-3), 289-305.

Yearley, S. (1995). The environmental challenge to science studies. pp. 457-479 in Jasanoff et al 1995.

Publisher's note Springer Nature remains neutral with regard to jurisdictional claims in published maps and institutional affiliations. 